\title{
The Description of Early Childhood Growth and Development with Online Learning Based on Authentic Assessments
}

\author{
I Wayan Karta* \\ Early childhood education programs \\ University of Mataram \\ Mataram, Indonesia \\ wayan_karta@unram.ac.id
}

\author{
Ni Wayan Rasmini \\ Early childhood education programs \\ |Institut Agama Hindu Negeri Gde Pudja \\ Mataram Indonesia
}

\begin{abstract}
The Covid-19 pandemic caused the education process in early childhood to be carried out at home by applying online methods. This requires a lot of adjustments from face-toface learning habits, which are currently seen as a source of the spread of Covid-19. This study aims to describe the growth and development of early childhood who are carrying out learning at home by applying the authentic assessment-based online method. Growth and development are divided into six aspects: physicalmotor, cognitive, language, social-emotional, artistic, and religious/moral. This research was conducted in the city of Mataram with the subject of 18 teachers-parents and 90 children aged 5-6 years. Students do online learning at home. Data collection was carried out through authentic assessment with observation and portfolio techniques. The data were analyzed descriptively qualitatively to get the results. The results of the analysis found that $20 \%$ of children developed very well, $38 \%$ developed according to expectations, $30 \%$ began to develop, and $12 \%$ had not developed. It can be concluded that learning from home by applying authentic assessment in early childhood has been able to stimulate children to achieve good growth and development. Learning from home using online methods based on authentic assessment facilitated by teacher-parents can be applied as an alternative solution to the problem of eliminating face-to-face learning in schools.
\end{abstract}

Keywords-Growth-Development, Online Learning, Authentic Assessment

\section{INTRODUCTION}

Early childhood education is the first and foremost education to realize self-potential into actual abilities, which consists of physical and spiritual aspects, as a whole and responsibly. Spiritual development, such as being clever, broad-minded, determined, considerate, dynamic, and creative, is carried out without neglecting the physical aspects. Early childhood is defined as a fully developed individual if there is a balance of development in the cognitive, affective, and psychomotor domains. The three developmental domains are divided into six aspects: physical-motor, cognitive, language, social-emotional, artistic, and moral/religious [1]. Early childhood development that builds six aspects of development aims to develop humans into adult humans who are responsible for themselves, able to maintain harmony among humans, preserve the environment in accordance with natural laws, and carry out obligations in accordance with moral and religious values.

In the covid-19 pandemic situation, early childhood learning is carried out at home and is collaborative-integrative between teachers and parents [2]. Teachers are obliged to plan to learn and evaluate learning outcomes. About $60 \%$ of kindergarten teachers are ready to carry out online learning, but the other $40 \%$ are still constrained by feelings of inferiority to online learning management and limited facilities [3]. The implementation of the e-learning policy during the Covid-19 period was not yet effective, because it was constrained by the limitations of teachers in terms of readiness, media, platforms, methods, evaluation tools, interaction, and student interest [4]. Parents act as mentors, educators, carers, developers, supervisors, and have a special role in ensuring that children adopt a clean and healthy lifestyle. Parents accompany children to do assignments, carry out joint activities, create a comfortable environment, communicate intensively, play together, act as models, and carry out variations/innovations in activities at home [5].

Learning activities in the form of games aim to stimulate standardized growth and development of children into six aspects of development: physical-motor, cognitive, language, social-emotional, art, and religion / moral. In online learning during Covid-19, there was a decrease in children's developmental achievement in the socio-emotional aspects, and there was an increase in the artistic aspect [6]. Two days a week the learning process is directly observed by the parent-teacher. On other days learning is carried out by parents, while teachers monitor through learning process documents sent by parents. The learning process that is prioritized in home learning activities is the initial, core, and closing activity. However, if the habituation and recalling activities can be carried out, it will be very good to complement the optimal achievement of children's growth and development.

Online assessment of early childhood learning at home is carried out authentically. Authentic assessment has several benefits, namely: measuring and identifying the competence of learning outcomes directly from student performance; encourage students to demonstrate meaningful performance in real situations; students construct learning outcomes based on their knowledge and analysis, and; integrating assessment 
activities with the learning process [7]. The assessment was carried out using two techniques, namely: observation in the form of observation and making anecdote notes, and a portfolio containing the learning process and children's best work after learning one theme. The difference in assessment techniques and the application of local values in applying the assessment does not affect the achievement of the developmental aspects [7].

The change in learning from face-to-face at school to learning at home using online methods is very radical. Home learning uses limited learning elements, so it requires adjustment. This causes the learning process and outcomes cannot be targeted as learning is carried out face-to-face in schools. Obstacles for parents in accompanying children to study at home during the Covid-19 pandemic, such as a lack of understanding of the material, difficulty fostering children's interest in learning, not having enough time to accompany children because they have to work, impatient in accompanying children to learn, difficulty operating gadgets, and the limited reach of internet services [8]. Online learning from home has several limitations, in terms of infrastructure, delivery of material, purchasing internet quotas, internet connection, visual learning styles, and limited student control abilities [9]. Some of the limitations of the learning process and outcomes are caused by limited infrastructure; varied finances; non-professional education management; competency of graduates cannot be standardized, learning content and learning process are not targeted optimally; educators are not standardized competence (personal, social, professional, pedagogical, and information technology literacy) [10]. Changes in learning situations and conditions, from learning at school to at home by applying online methods, have many limitations. This certainly affects the development of children. So it becomes very necessary to conduct a scientific study of the description of early childhood development in online learning from home based on authentic assessment.

\section{METHODS}

This research is classified as qualitative descriptive research with the subject of 18 old teachers and 90 students aged 5-6 years who carry out online learning and authentic assessment in the city of Mataram. The research was conducted from July to November 2020. The implementation of authentic assessmentbased learning was carried out by interviewing educators and observing the learning process using interview guidelines and structured observation. Student learning outcomes in the form of child development are collected through observation of play activities and analysis of children's work. The instrument used is valid and in accordance with the growth and development indicators that apply nationally in Indonesia according to the Minister of National Education Regulation No. 137/2014. The content of each aspect of planning, implementation, assessment, and indicators of student growth is compiled into a guideline for observation and interviews. The data obtained is in the form of qualitative descriptive data whose validity is tested with credibility techniques using steps to extend the observation time and expand the target subject. Data improvement and verification activities are carried out through reflection activities in the Focus Group Discussion.
The types of data obtained, such as planning and implementation of learning data, are classified into qualitative ordinal data on four scales. The scale starts from not good, good enough, good, and very good. The data on student growth and development were obtained in the form of grade data, starting from underdeveloped, that is, children have not shown developmental indicators according to their age; Starting to develop, that is, children can behave according to developmental indicators if facilitated by educators; Developing according to expectations, that is, children can show indicators of development according to their age independently; developing very well, that is, the child has shown behavior according to the indicators of optimal development, and can facilitate other friends. Descriptive ordinal data analysis was carried out by calculating the average percentage, while the qualitative data analysis used an inductive analysis model to understand the learning process and children's development based on facts. The stages of analysis are divided into 1) observing the learning phenomenon, identifying, revising, and checking double data; 2) categorizing the information obtained; 3 ) explore and explain categorization; 4) explain categorization relationships; 5) draw general conclusions; 6) build or explain the theory [11].

\section{RESULTS AND DISCUSSION}

The process of preparing early childhood learning plans begins with organizing developmental aspects according to the characteristics of early childhood. Several indicators must be done, such as teachers identify early childhood characteristics related to the scope of development; identify children's early abilities in six aspects of development; organize a play environment that facilitates early childhood in the six spheres of development; ensure all young children have the opportunity to actively participate in learning activities through play; make notes on the development of early childhood abilities within the scope of six developments; identify difficulties experienced by early childhood in the six developmental spheres and help overcome them; provide learning opportunities for all early childhood children with special needs (not found). The teacher then analyzes play theory according to the aspects and stages of development, needs, potentials, talents, and interests of the child. This aspect consists of several indicators, namely: being able to choose the method of learning through playing; using learning through play methods; designing learning activities that support children's creativity indoors and outdoors; designing meaningful thematic learning activities in accordance with basic competencies.

Learning activities consist of several indicators, namely: creating a pleasant atmosphere of play so that children are enthusiastic about learning, carrying out meaningful thematic learning activities by linking children's daily experiences, doing good habits in children, carrying out learning using a scientific approach, and utilize media and learning resources found in the surrounding environment with a scientific approach. The early childhood development and development assessment is designed based on an authentic assessment that applies observations about daily activities, anecdote notes, and work analysis. Daily observations are made by making notes on children's activities in playing and outside playing activities. 
Observations were made by making anecdote notes containing specific behaviors in children, both positive and negative behavior. Observations are made by analyzing the children's work to describe the completeness of the elements, the adequacy of the content, and the holistic meaning according to the theme and type of activity. The aspects of early childhood development consist of six aspects: moral and religious values, socioemotional, language, cognitive, physical motoric, and art. The results of the authentic assessment were converted into four categories, namely: underdeveloped, starting to develop, developing according to expectations, and developing very well.

The teacher's ability to organize aspects of development according to the characteristics of the child in the preparation of a lesson plan has been carried out in good categories. The maximum ability has been carried out by the teacher on several indicators, such as the teacher has identified the characteristics of the child, with their data that they have a record of nature, habits, and behavior related to religious and moral values, physical motor, cognitive, socio-emotional, language and art. . The teacher has identified the child's ability to use an instrument for early detection of child development which includes physical measures and mental and spiritual development. The teacher has arranged the play environment both indoors and outdoors, ensuring the play environment is safe, clean, fun, and stimulates children's curiosity. The teacher has notes about the development of children's abilities in the six areas of development that are contained in observational notes, anecdote notes, and notes of work. The teacher identifies difficulties experienced by children in the six spheres of development and helps to overcome them.

The difficulties experienced by teachers in organizing development according to children's characteristics still occur in the indicators of providing opportunities for children to actively participate in learning activities through play. Teachers do not optimally explore data for children with special needs, do not have a portfolio of children with special needs, do not have individual learning programs for children with special needs, and have not optimal equality of services for children with special needs with other children.

Activities to analyze play theory according to the aspects and stages of development, needs, potentials, talents, and interests have been done very well. All standards have been met in terms of choosing learning methods through play in accordance with the six areas of development and designing learning activities that support children's creativity indoors and outdoors. Several things have not been optimally done by the teacher to analyze the theory of play. The lack of teachers appears in designing learning themes according to the principles of being meaningful, interesting, according to children's interests, and simple.

The ability of teachers to design early childhood development activities has been optimal in several indicators, namely: designing play activities in the form of semester programs by determining basic competencies, themes, and subthemes, as well as allocating time as needed; and designing play activities in the form of a weekly catch-up implementation plan by determining basic competencies, materials, and plans for learning activities in one week. There are still weaknesses of teachers in designing child development activities in making development plans and learning content as well as standard operating procedures for learning; ability to design play activities in the form of daily learning implementation plans; and in terms of determining basic competencies, materials, tools and materials for play, opening, core, and closing activities and assessment plans. The results of descriptive analysis of the teacher's ability to plan the implementation of learning were classified as good with an average of $71.67 \%$ of 18 teachers.

Indicators of learning and playing activities at home have been implemented optimally on several indicators, namely: the ability to create a pleasant atmosphere for play, so that children are enthusiastic about learning; educators organize learning places that are attractive, neat, and beautiful; using a variety of media in learning activities according to the theme; using a variety of interesting learning methods, and create a friendly learning atmosphere. Educators have optimally carried out good habits in children, by giving examples of good behavior repeatedly, conveying play sequences to children repeatedly, and providing support to children who are not used to behaving repeatedly. Educators still have several obstacles: their ability is less than optimal in terms of carrying out meaningful thematic learning activities by linking children's daily experiences; less optimal in carrying out learning using a scientific approach, and the use of media, as well as learning resources available in the surrounding environment. Descriptively, the ability of teachers and parents to carry out learning at home online found that the average rate of $70 \%$ of the 18 educators was categorized as quite good.

The description of early childhood development during home learning conducted online by teachers and parents is divided into aspects of moral development and religious values generally show behavior develops as expected, can pray before and after activities, pray before and After eating, can carry out simple prayer movements, and have memorized a few short prayer verses; knowing God as the creator, which appears when the child says that he is God's creation; children are able to recognize good behavior which is shown by being helpful and sharing with friends about food and toys; children enjoy listening to stories that contain religious values and love others; and, children can give and answer greetings, are able to give and apologize if they make mistakes and can lead a simple prayer.

In the aspect of socio-emotional development, children generally have developed according to expectations. In playing activities, the behavior appears able to play, share toys and food with others, be able to make their own decisions when choosing activities, be able to complete individual or group assignments, always be enthusiastic about being the required officers, be patient waiting their turn, tidy up play tools, show a tolerant attitude, and happy to help friends who are experiencing difficulties, even though there are children who still solve problems by crying. In general, children know their own emotions, can tell stories when they are happy and sad and can obey the rules that have been agreed upon, although some children still need to be reminded by educators. 
In the aspect of language development, the results of observations show that all research subjects have been able to carry out two to three simple commands, can mention their names, parents, gender, home address simply. However, some children still need guidance from teachers or parents in the pronunciation of the letter symbols in their names. Disclosure of language is communicative, able to express pleasure or displeasure with an event that has been experienced, able to tell the experience of playing at home with complex sentences, able to ask and answer questions related to the theme, and able to convey information heard from teachers to parents. In terms of literacy language skills, children are able to recognize and distinguish letter sounds very well, are able to group pictures that have the same initial letters and are related to themes, and are starting to be able to read short words and sentences. Can tell the work made to others, children can write their names smoothly and correctly, children are able to listen to educators' instructions with the right response. The ability to listen begins to appear when children make works from paper that have been given a pattern, then they are torn into small pieces to form a complete human body. Most children in terms of language development have developed according to expectations.

In the aspect of cognitive development, children are able to recognize and mention the names of family members and friends, as well as their special characteristics in more detail such as skin color and hair color. They can already say the names of numbers 1 to 10 that represent objects, even some children are able to say numbers up to 20 . Children can also name the names of the days in a week and the names of the months in a year, although they are still random. Can imitate various vowel and consonant symbols without seeing, for example, be able to match a number of objects with numeric symbols correctly, be able to solve simple problems, such as distinguishing geometric shapes, make miniature toys from media, and unload pairs of aircraft, pistols, and miniature houses.

Physical motor development, gross and fine motor skills of children have appeared. Children can move swiftly and flexibly in jumping, climbing, running, and always maintaining personal hygiene by washing their hands before and after activities. Children can jump using one leg, run faster and more balanced, can kick and catch the ball with their playmates. The development of fine motor skills has appeared several things, such as being able to hold a pencil correctly, being able to cut a certain pattern, being able to carry out a collage with seeds that can follow a pattern well, being able to walk in various directions in various ways, for example walking forward on a line. straight, walk on the boardwalk, walk forward on your heels, tiptoe, and back and forth. Running with light objects, swinging, and creeping in tire tunnels. In general, physical motor development has developed as expected.

The development of the artistic aspect can be seen from the emergence of children's joy in participating in dancing, drum band, and coloring activities. Everything is carried out with great enthusiasm, when dancing, you can follow dance movements, drum rhythms, and color neatly. Can make hats from old newspapers, be creative in making trash cans using cardboard, wooden twigs, and old newspapers. Children can follow every beat of a musical instrument according to the direction of the educator to accompany several songs, such as: moving forward without fear, riding the train, and motherly love. Children can construct simple building shapes from blocks and can sing complete songs worthy of a thumbs up.

Description of the development of 90 children based on six developmental phases, it was found that 18 people $(20 \%)$ developed very well, 34 people $(38 \%)$ developed as expected, 27 people $(30 \%)$ started to develop and 11 people $(12 \%)$ had not developed. If evaluated based on learning completeness, it was found that 52 people $(58 \%)$ had completed their development results and 38 people (42\%) had not finished. It can be interpreted that online learning in collaboration with teachers and parents in early childhood carried out from home has been quite successful in developing six aspects of early childhood development, although a small proportion of 11 people (12\%) are still classified as underdeveloped.

Early childhood development is an integrative holistic behavior from six aspects of development, namely physicalmotor, cognitive, language, socio-emotional, art, religion, and morals, which in the realm of learning are always called cognitive, affective, and psychomotor. This is relevant to Bandura's Social Cognitive Theory which states the importance of social influence on behavior, individuals acquire knowledge, rules, skills, strategies, beliefs, and emotions by observing other individuals. Individuals act based on their thoughts, goals, beliefs, and values [12]. Understanding the achievement of initial competencies and the potential for the prevention of ongoing low achievement is very important to be preceded by holistic measures of school readiness, cognitive and noncognitive areas [13] Reading achievement as a product of independent behavior in learning is fully mediated by the relationship between school-based parental participation [14]. Socio-emotional development can be facilitated by cooperative learning. Children taught by cooperative learning have higher growth and development than traditional classes [15].

Interaction-based learning has a positive effect on student academic achievement [16]. Early childhood learning requires structuring the environment so that it is comfortable, safe, and educative. A healthy learning environment and a conducive climate based on local culture affect children's learning outcomes [17]. In addition, the ability of teachers and parents to teach and master the material has a considerable effect on children's growth and development. Plans for the implementation of learning, the implementation of play or learning activities also affect children's growth and development. The function, meaning and usefulness of the lesson plan play an important role in helping educators become pedagogical learners [18]. The role of internally produced learning tools can affect the learning skills of children living in resource-poor communities [19].

The implementation of early childhood learning is an interaction between educators and students and learning resources in the form of games. The potential that exists within the child and outside himself, such as the environment, facilities, learning resources, and all efforts to achieve certain learning 
goals, will determine the quality of the learning process [20]. Positive discipline and strategies in the learning process from educators and school principals have a positive relationship to student motivation in learning [21]. An authentic assessmentbased mobile learning approach can increase student interest, attitudes, and learning outcomes [22]. Holistic teacher-student attitudes and interactions are positively associated with learning achievement [23]. Implementation of learning plans in the implementation of play activities for early childhood carried out continuously and collaborating with authentic assessments. Learning assessments carried out during the learning process, using observation techniques, anecdote notes, and work, greatly support the objectivity of the description of early childhood growth and development.

Generally, early childhood learns through play. This is in accordance with the characteristics of children who are active in exploring their environment. The learning process that is carried out departs from the potential of the child. Enabling children's knowledge of the setting, formulating clear and specific goals before learning activities, can develop student achievement strategies [24]. Rationally, a child's growth and development are determined by the ability, effort, and difficulty of the task, but irrationally there is still a luck factor that affects the outcome of learning. While cognitive development is based on social cognitive theory which states that the cognitive aspect is the causal contribution of the thought process to children's motivation, attitudes, and actions, this theory describes children as dynamic organisms in processing information and as social beings [25].

\section{CONCLUSION}

The results of the qualitative descriptive analysis of the teacher's ability to plan the implementation of learning were classified as good, and the implementation of learning carried out at home online by the teacher and parents was categorized as quite good. Online learning in early childhood which is carried out from the home of the collaboration of teachers and parents, is quite successful in developing six aspects of early childhood development. It is expected that teachers and parents together formulate a plan for implementing learning well, through activities to organize developmental aspects according to the characteristics of early childhood; analyzing play/learning theory according to the aspects and stages of development, needs, potentials, talents, and interests of children; compiling an implementation plan for early childhood development learning based on the curriculum, which consists of the preparation of standard operating procedures, semester programs, weekly learning implementation plans, and daily learning implementation plans, based on applicable guidelines. In the implementation of online learning from home facilitated by teachers and parents, it is necessary to unify perceptions and competencies in managing quality learning for early childhood..

\section{REFERENCES}

[1] Permendikbud, N. 137 T. 2014. (2014). Tentang Standar PAUD Memuat Standar PAUD dan No 146 Tentang Kurikulum PAUD. Depdikbud.

[2] Hewi, L., \& Asnawati, L. (2020). Strategi Pendidik Anak Usia Dini Era Covid-19 dalam Menumbuhkan Kemampuan Berfikir Logis. Jurnal
Obsesi: Jurnal Pendidikan Anak Usia Dini, 5(1), 158. https://doi.org/10.31004/obsesi.v5i1.530

[3] Ayuni, D., Marini, T., Fauziddin, M., \& Pahrul, Y. (2020). Kesiapan Guru TK Menghadapi Pembelajaran Daring Masa Pandemi Covid-19. Jurnal Obsesi: Jurnal Pendidikan Anak Usia Dini, 5(1), 414. https://doi.org/10.31004/obsesi.v5i1.579

[4] Nurkolis, N., \& Muhdi, M. (2020). Keefektivan Kebijakan E-Learning berbasis Sosial Media pada PAUD di Masa Pandemi Covid-19. Jurnal Obsesi: Jurnal Pendidikan Anak Usia Dini, 5(1), 212. https://doi.org/10.31004/obsesi.v5i1.535

[5] Kurniawan, I. S., \& Toharudin, U. (2017). Values of Local Wisdom: A Potential to Develop an Assessment and Remedial. International Journal of Evaluation and Research in Education (IJERE), 6(1), 71. https://doi.org/10.11591/ijere.v6i1.6349

[6] Wulandari, H., \& Purwanta, E. (2020). Pencapaian Perkembangan Anak Usia Dini di Taman Kanak-kanak selama Pembelajaran Daring di Masa Pandemi Covid-19. Jurnal Obsesi : Jurnal Pendidikan Anak Usia Dini, 5(1), 452. https://doi.org/10.31004/obsesi.v5i1.626

[7] Susani, R. G. (2018). the Implementation of Authentic Assessment in Extensive Reading. International Journal of Education, 11(1), 87. https://doi.org/10.17509/ije.v11i1.9113

[8] Wardani, A., \& Ayriza, Y. (2020). Analisis Kendala Orang Tua dalam Mendampingi Anak Belajar di Rumah Pada Masa Pandemi Covid-19. Jurnal Obsesi: Jurnal Pendidikan Anak Usia Dini, 5(1), 772. https://doi.org/10.31004/obsesi.v5i1.705

[9] Satrianingrum, A. P., \& Prasetyo, I. (2020). Persepsi Guru Dampak Pandemi Covid-19 terhadap Pelaksanaan Pembelajaran Daring di PAUD. Jurnal Obsesi : Jurnal Pendidikan Anak Usia Dini, 5(1), 633. https://doi.org/10.31004/obsesi.v5i1.574.

[10] Nurdin, N., \& Anhusadar, L. (2020). Efektivitas Pembelajaran Online Pendidik PAUD di Tengah Pandemi Covid 19. Jurnal Obsesi : Jurnal Pendidikan Anak Usia Dini, 5(1), 686. https://doi.org/10.31004/obsesi.v5i1.699

[11] Bungin, B. (2012). Penelitian Kualitatif, Edisi Kedua (Edisi Kedu). Kencana Prenada Media Group.

[12] Dale H. Schunk, Paul R. Pintrich, J. L. M. D. E. T. (2012). Motivasi dalam Pendidikan Teori, Penelitian, dan Aplikasi (Edisi Keti). PT Indeks.

[13] Scott Daviesa, \& MagdalenaJanusbEricDukubAshleyGaskinb. (n.d.). Using the Early Development Instrument to examine cognitive and noncognitive school readiness and elementary student achievement. Early Childhood Research Quarterly, Volume 35, Pages 63-75. https://doi.org/10.1016/j.ecresq.2015.10.002

[14] R.Daniela, G., \& Berthelsenb1, C. W. D. (2016). Early school-based parent involvement, children's self-regulated learning and academic achievement: An Australian longitudinal study. Early Childhood $\begin{array}{llll}\text { Research } & \text { Quarterly, } & 368-177 .\end{array}$ https://doi.org/10.1016/j.ecresq.2015.12.016

[15] Ajaja, O., \& Eravwoke, O. (2011). Effects of cooperative learning strategy on junior secondary school students achievement in integrated science. Electronic Journal of Science Education, 14(1), 1-18.

[16] Parveen, Q., Yousuf, M. I., \& Mustafa, S. (2017). An experimental study on the effect of cooperative learning on students' academic achievement and students' perceptions towards cooperative learning. The Anthropologist, 27(1-3), 69-76. https://doi.org/10.1080/09720073.2017.1311670

[17] MacNeil, A. J., Prater, D. L., \& Busch, S. (2009). The effects of school culture and climate on student achievement. International Journal of $\begin{array}{lll}\text { Leadership in } & \text { Education, } & \text { 12(1), }\end{array}$ https://doi.org/10.1080/13603120701576241

[18] Karen E Johnson, A. K. D. (n.d.). How ‘sign meaning develops': Strategic mediation in learning to teach. https://doi.org/https://doi.org/10.1177/1362168813494126

[19] Borzekowski, • Dina L. G., Lando, • Agnes Lucy, \& $\bullet$ Sara H. Olsen, \& Giffen, - Lauren. (2019). The Impact of an Educational Media Intervention to Support Children's Early Learning in Rwanda. International Journal of Early Childhood, volume 51, 
[20] Sanjaya, W. (2010). Strategi Pembelajaran Berorientasi Standar Proses Pendidikan. Prenada Media Group.

[21] Somayeh, G. (2013). Investigating the Effect of Positive Discipline on the Learning Process and its Achieving Strategies with Focusing on the Students ' Abilities. World of Science Journal, 3(5), 305-315.

[22] Hwang, G. J., \& Chang, H. F. (2011). A formative assessment-based mobile learning approach to improving the learning attitudes and achievements of students. Computers and Education, 56(4), 1023-1031. https://doi.org/10.1016/j.compedu.2010.12.002

[23] Roorda, D. L., Jak, S., Zee, M., Oort, F. J., \& Koomen, H. M. Y. (2017). Affective teacher-student relationships and students' engagement and achievement: A meta-analytic update and test of the mediating role of engagement. School Psychology Review, 46(3), 239-261. https://doi.org/10.17105/SPR-2017-0035.V46-3

[24] Malmberg, J., Järvenoja, H., \& Järvelä, S. (2013). Patterns in elementary school students' strategic actions in varying learning situations. Instructional Science, 41(5), 933-954. https://doi.org/10.1007/s11251012-9262-1

[25] Olson, B. R. H. \&Matthew H. D. B. T. W. B. S. (2010). Theories Of Learning (Teori Belajar) (Edisi Ketu). Kencana Prenada Media Group. 